\title{
Assessing environmental impacts associated with freshwater consumption along the life cycle of animal products: the case of Dutch milk production in Noord-Brabant
}

\author{
Imke J. M. De Boer • Idse E. Hoving • \\ Theun V. Vellinga • Gerrie W. J. Van de Ven • \\ Peter A. Leffelaar • Pierre J. Gerber
}

Received: 20 July 2011 / Accepted: 15 May 2012 /Published online: 1 June 2012

(C) The Author(s) 2012. This article is published with open access at Springerlink.com

\begin{abstract}
Purpose The assessment of water footprints of a wide range of products has increased awareness on preserving freshwater as a resource. The water footprint of a product was originally defined by Hoekstra and Hung (2002) as the sum of the volumetric water use in terms of green, blue and grey water along the entire life cycle of a product and, as such, does not determine the environmental impact associated with freshwater use. Recently, several papers were published that describe building blocks that enable assessment of the site-specific environmental impact associated with freshwater use along the life cycle of a global food chain, such as the impact on human health (HH), ecosystem quality (EQ) or resource depletion (RD). We integrated this knowledge to enable an assessment of the environmental
\end{abstract}

Responsible editor: Annette Koehler

I. J. M. De Boer $(\bowtie)$

Animal Production Systems Group, Wageningen University, P.O. Box 338, 6700 AH, Wageningen, The Netherlands e-mail: Imke.deBoer@wur.nl

I. E. Hoving $\cdot$ T. V. Vellinga

Wageningen UR Livestock Research,

P.O. Box 65,8200 AB, Lelystad, The Netherlands

G. W. J. Van de Ven • P. A. Leffelaar

Plant Production Systems Group, Wageningen University,

P.O. Box 430, 6700 AK, Wageningen, The Netherlands

P. J. Gerber

Animal Production and Health Division,

Food and Agricultural Organization,

Viale delle Terme di Caracalla,

00153 Rome, Italy impact associated with freshwater use along the life cycle of milk production, as a case for a global food chain.

Material and methods Our approach innovatively combined knowledge about the main impact pathways of freshwater use in life cycle assessment (LCA), knowledge about sitespecific freshwater impacts and knowledge about modelling of irrigation requirements of global feed crops to assess freshwater impacts along the life cycle of milk production. We evaluated a Dutch model farm situated on loamy sand in the province of Noord-Brabant, where grass and maize land is commonly irrigated.

Results and discussion Production of $1 \mathrm{~kg}$ of fat-and-protein corrected milk (FPCM) on the model farm in Noord-Brabant required $66 \mathrm{~L}$ of consumptive water. About $76 \%$ of this water was used for irrigation during roughage cultivation, $15 \%$ for production of concentrates and $8 \%$ for drinking and cleaning services. Consumptive water use related to production of purchased diesel, gas, electricity and fertiliser was negligible (i.e. total $1 \%$ ). Production of $1 \mathrm{~kg}$ of FPCM resulted in an impact on $\mathrm{HH}$ of $0.8 \times 10^{-9}$ disability adjusted life years, on EQ of $12.9 \times 10^{-3} \mathrm{~m}^{2} \times$ year and on RD of $6.7 \mathrm{~kJ}$. The impact of producing this kilogram of FPCM on RD, for example, was caused mainly by cultivation of concentrate ingredients, and appeared lower than the average impact on $\mathrm{RD}$ of production of $1 \mathrm{~kg}$ of broccoli in Spain.

Conclusions Integration of existing knowledge from diverse science fields enabled an assessment of freshwater impacts along the life cycle of a global food chain, such as Dutch milk production, and appeared useful to determine its environmental hotspots. Results from this case study support earlier findings that LCA needs to go beyond simple water volume accounting when the focus is on freshwater scarcity. The approach used, however, required high-resolution inventory global data (i.e. 
especially regarding crop yield, soil type and root depth), and demonstrated a trade-off between scientific quality of results and applicability of the assessment method.

Keywords Animal production - Consumptive water use Life cycle assessment. Water footprint

\section{Introduction}

Freshwater is essential for human well-being and ecosystem quality. Humans need water for drinking, food production and hygiene, whereas it is indispensable to biodiversity and ecosystem functions such as the control of climate (Koehler 2008). The assessment of water footprints of a wide range of products has increased awareness of preserving freshwater as a resource (Chapagain et al. 2006; Chapagain and Orr 2009; Mekonnen and Hoekstra 2010a; 2010b; Ridoutt et al. 2009).

The water footprint concept was originally introduced by Hoekstra and Hung (2002) and is now defined by the Water Footprint Network as the sum of the volumetric water use in terms of green, blue and grey water along the entire life cycle of a product (Hoekstra et al. 2009). Based on this concept, Mekonnen and Hoekstra (2010b), for example, quantified that industrial production of $1 \mathrm{~kg}$ of Dutch eggs required about $1,355 \mathrm{~L}$ of water, whereas the world average for production of $1 \mathrm{~kg}$ of cheese is $5,984 \mathrm{~L}$ of water. The original concept of the water footprint, however, focuses on water volume accounting only and does not consider the environmental impact associated with water consumption (Ridoutt et al. 2010a). To deepen the discussion of freshwater use along the life cycle of a product, we propose it is important not to only quantify its volumetric use but to also assess the environmental impact associated with its use along the entire life cycle.

Green water, as defined by Hoekstra et al. (2009), refers to precipitation on land that does not run-off or recharge an aquifer and is stored in the upper part of the rooted soil or temporarily stays on top of vegetation. This part of precipitation eventually can evaporate or transpire through soils and crops or can be embodied in crop material. In case it would not be cultivated, however, the natural ecosystem might evaporate and transpire a similar amount of green water. Green water use, therefore, does not generally have an impact on the environment (Pfister et al. 2009; Milà i Canals et al. 2009). Only possible changes in infiltration or run-off, due to land use or management changes, might have an impact on the environment.

Blue water use, as defined by Hoekstra et al. (2009), includes consumptive water use. Water is considered consumed if it is withdrawn from an aquifer, a lake or a river, and not discharged into the same watershed because it evaporates, is embodied in crop or animal products, or is discharged into a different watershed (Bayart et al. 2010), such as irrigation water evaporated by feed crops or tap water used as drinking water for animals. Blue water use, therefore, can have an impact on human health and ecosystem quality or can result in depletion of water resources (Pfister et al. 2009). The impact of freshwater use on human health, ecosystem quality or resource depletion, however, is site-specific. The effect of withdrawing $1 \mathrm{~m}^{3}$ of freshwater on ecosystem quality, for example, could be, on average, 43 times higher in Egypt than in the Netherlands because of the differences in water-limited plant growth and in annual precipitation (Pfister et al. 2009).

Grey water use, as defined by Hoekstra et al. (2009), refers to a virtual amount of water that is required to dilute the load of pollutants based on existing water quality standards. Grey water use of an animal product, therefore, is an indirect measure of the effect of producing that product on water quality issues, such as eutrophication or eco-toxicity, and should be considered in as such a life cycle assessment of animal products.

This paper will focus on environmental impact associated with consumptive freshwater use (i.e. blue water use) along the life cycle of an animal product because water use of the livestock sector (including feed production) exceeds $8 \%$ of the global water use (Steinfeld et al. 2006). Life cycle assessment (LCA) typically is a technique that evaluates the environmental impact of a product along its entire life cycle (Guinee et al. 2002). Several recent papers contain the elements that enable the assessment of site-specific environmental impacts associated with freshwater use along the life cycle of an animal product (Milà i Canals et al. 2009; Pfister et al. 2009; Bayart et al. 2010; Berger and Finkbeiner, 2010; Ridoutt and Pfister 2010). In particular, Milà i Canals et al. (2009) identified the main impact pathways of freshwater use in agricultural production, and Pfister et al. (2009) determined corresponding characterization factors for 175 countries in the world and their different watersheds. Furthermore, the UNEP-SETAC life cycle initiative (Bayart et al. 2010) has established a framework including harmonised terminology, and AQUASTAT can be used to determine consumptive water use of feed crops, often originating from all over the world (Eliasson et al. 2003). The objective of this paper was to integrate this recent knowledge to assess the environmental impact associated with consumptive freshwater use along the life cycle of a global animal food chain. We took Dutch milk production in Noord-Brabant as a case study.

\section{Material and methods}

\subsection{Definition of basic terminology}

This paper focuses on environmental impact associated with consumptive freshwater use (i.e. blue water use). Consumptive 
water use includes water withdrawn from a watershed (i.e. aquifer, stream, lake) that is not discharged into the same watershed because it evaporates, is embodied in crop or animal products or is discharged into a different watershed. Degradative water use means that water is withdrawn and discharged into the same watershed, while in the mean time its quality is degraded (Bayart et al. 2010). Degradative use of freshwater might result in water pollution, such as eutrophication or eco-toxicity, and should be considered separately in an LCA of animal products.

Consumptive water use can include both in-stream and off-stream water use. In-stream freshwater use is in situ use of water for, e.g., hydropower generation; whereas offstream water use is the use of water that is first removed from a natural water body. Examples of in-stream and offstream consumptive water use along the life cycle of animal products are in Table 1.

Furthermore, freshwater is a generic term covering all types of freshwater resources. Three main types of (abiotic) resources are distinguished: deposits, funds and flows (Finnveden 1996; Guinée et al. 2002; Lindeijer et al. 2002). A deposit or stock is a resource that is only very slightly or not regenerated within a human's lifetime, like a fossil fuel (regeneration rate around zero). A freshwater deposit, therefore, is exhausted when tapped. A fund has a natural renewability that allows it to regenerate as long as it is not irreversibly impaired (low regeneration rate). Water aquifers are considered as a deposit or a fund. Lakes are considered as a fund, whereas streams and rivers as water flows. They form a continuous water flow from which humans can withdraw certain quantities (high regeneration rate). In principle, a water flow is non-exhaustible. However, withdrawing more than $50-80 \%$ of the annual water flow (the exact figure depending on the local conditions) leads to water stress, as water is also required for environmental use and ecosystem services (Smakthin et al. 2004; Oki and Kanae 2006).

Table 1 Examples of consumptive use of in-stream and off-stream water in the life cycle of animal products

\begin{tabular}{ll}
\hline In-stream use & Off-stream use \\
\hline $\begin{array}{c}\text { Additional evaporation of water } \\
\text { from rivers due to transport of } \\
\text { feed or hydropower generation } \\
\text { (if used) }\end{array}$ & $\begin{array}{c}\text { Evapotranspiration of blue water } \\
\text { during cultivation of feed } \\
\text { ingredients }\end{array}$ \\
$\begin{array}{c}\text { Evaporation of water during } \\
\text { in-stream electricity production }\end{array}$ & $\begin{array}{c}\text { Unused irrigation water discharged } \\
\text { into a different watershed. } \\
\text { Water embodied in crop or animal } \\
\text { products }\end{array}$ \\
& Use of tap water for industrial or \\
& agricultural processes \\
\hline
\end{tabular}

\subsection{The case of Dutch milk production}

The methodology was illustrated for a Dutch milk production unit in Noord-Brabant. We assessed the environmental impact associated with freshwater use along the life cycle of milk production up to the moment that milk leaves the farm gate for the year 2008. This cradle-to-farm gate LCA (Fig. 1) included freshwater use related to cultivation of crops used to produce purchased feed (i.e. concentrates and roughage), the processing of concentrates at the feed mill, production of energy and artificial fertiliser purchased by the dairy farm, on-farm cultivation of grass or maize, and water required for dairy cattle husbandry (e.g. drinking and cleaning water). Freshwater use related to transport of feed ingredients to the feed mill and from the feed mill to the farm were included also.

LCA relates the environmental impact to a functional unit, which is the main function of the production system expressed in quantitative terms. Freshwater use impacts were fully allocated to the functional unit of $1 \mathrm{~kg}$ of fatand-protein corrected milk (FPCM; CVB 2008).

General characteristics of the model dairy farm analysed are presented in Table 2. The model farm was assumed to be situated on loamy sand in the province of Noord-Brabant (Latitude: $52^{\circ}$; Longitude: $5^{\circ}$ ). In total, each dairy cow used about 2.6 tonnes of concentrates per year (i.e. $90 \%$ dry matter (DM)). Table 3 shows the average composition of concentrates assumed, the country in which the original crop of each feed ingredient was assumed to be cultivated (Nevedi 2008; PDV (2010) Product board for Animal Feed,

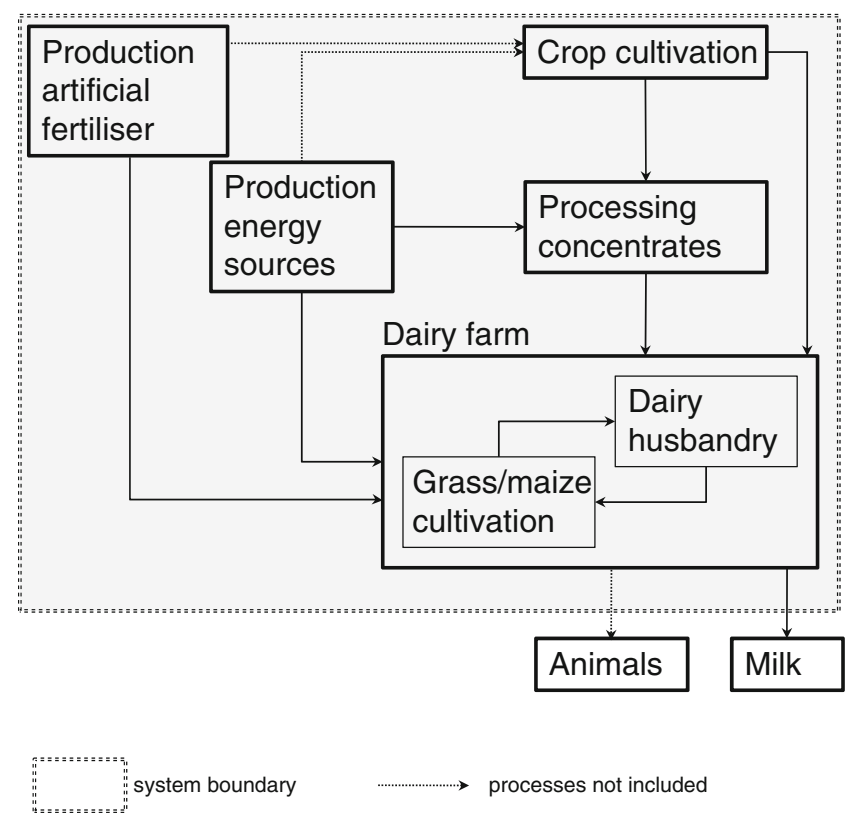

Fig. 1 Processes (including transport) along the life cycle of milk production included in consumptive water assessment 
Table 2 General characteristics of the dairy farm analysed

\begin{tabular}{|c|c|}
\hline Characteristic (unit) & Number \\
\hline Quota (tonnes FPCM) & 547 \\
\hline Hectares (ha) & 23.3 grass, 8.7 maize \\
\hline Number of milking cows $(n)$ & 56 \\
\hline Milk production per cow (kg FPCM year ${ }^{-1}$ ) & 9,771 \\
\hline Concentrates $\left(\mathrm{kg} \mathrm{cow}^{-1}\right.$ year $\left.^{-1}\right)$ & 2,564 \\
\hline Purchased maize (tonnes DM year ${ }^{-1}$ ) & 16.5 \\
\hline $\mathrm{N}$-Fertilisation $\left(\mathrm{kg} \mathrm{N}_{\text {year }}{ }^{-1}\right)$ & 4,613 \\
\hline P-Fertilisation $\left(\mathrm{kg} \mathrm{P}_{2} \mathrm{O}_{5}\right.$ year $\left.^{-1}\right)$ & 423 \\
\hline Diesel use (L year ${ }^{-1}$ ) & 3,500 \\
\hline Electricity use (kWh year $\left.{ }^{-1}\right)$ & 50,107 \\
\hline \multicolumn{2}{|l|}{ Irrigation water used } \\
\hline Grassland & $25-128 \mathrm{~mm} / \mathrm{ha}^{\mathrm{a}}$ \\
\hline Maize land & $21-62 \mathrm{~mm} / \mathrm{ha}^{\mathrm{a}}$ \\
\hline
\end{tabular}

Data are based on model dairy farm located in Noord-Brabant

FPCM fat-and-protein corrected milk (CVB 2008)

${ }^{\text {a }}$ Range from 2008 to 2010

personal communication), the kilogram DM of the original crop required to produce $1 \mathrm{~kg}$ DM of feed ingredient and the economic allocation factor used. Economic allocation implies that the environmental impact of crop cultivation or crop processing was allocated to various crop products based on their relative economic value. We used economic allocation for production of feed ingredients because this allocation method is mostly used in LCAs of milk products (De Vries and de Boer, 2010) and recommended by International Dairy Federation guide for LCA (IDF, 2010). Water use required for cultivation of citrus pulp and palm kernel expeller was excluded from the analysis due to their low economic allocation factor.

\subsection{Computation of consumptive freshwater use} along the life cycle of milk production

For each stage in Fig. 1, we describe how different forms of consumptive water enter or leave the stage and how we computed this water use. Subsequently in "Section 2.4" we describe how to determine the environmental impact associated with this water use.

\subsubsection{Consumptive freshwater use required for crop and pasture cultivation}

The amount of freshwater required to cultivate a crop that is used to produce animal feed can originate from precipitation on land (i.e. rainfed situation) or, if water demand for crop growth exceeds the availability of rainwater, from supplemental irrigation. We assumed all irrigation water being consumptive water use, i.e. implying that irrigation losses did not return to the same watershed, which represents a worst-case scenario.

Besides irrigation water, crop production indirectly uses consumptive water because it uses fertilisers and fossil energy, i.e. inputs that require water during their production process. Due to changes in crop management or land use, infiltration and run-off of rainwater might change, which might affect water availability of ecosystems.

In order to assess the environmental impact of freshwater use from cultivation of a crop, we summed (1) the amount of consumptive water required to irrigate a crop, (2) the amount of consumptive water required to produce inputs for the cultivation of grass and maize on-farm (i.e. artificial fertilisers, and fossil energy), and (3) the change in infiltration and run-off of rainwater due to changes in land use. Finally, the freshwater use of $1 \mathrm{~kg}$ of DM feed ingredient was computed by multiplying the freshwater use of the original crop with the amount of the original crop required to produce $1 \mathrm{~kg} \mathrm{DM}$ of feed ingredient and an economic allocation factor (see Table 3).

(1) Irrigation water The amount of irrigation water required during crop cultivation was computed based on regional climatic data, information about soil type and actual yield data (Fig. 2). In order to retrieve consistent data across crops, we used global databases and models, as concentrate
Table 3 Relative share of various feed ingredients in concentrate, country of origin, ratio of kilogram DM of the original crop required to produce $1 \mathrm{~kg}$ $\mathrm{DM}$ of feed ingredient and economic allocation factor used

$A R$ Argentina, $B E$ Belgium, $B R$ Brazil, $I N$ India, $I D$ Indonesia, $D E$ Germany, FR France, $N L$ the Netherlands

\begin{tabular}{lrlll}
\hline Ingredients & \multicolumn{1}{c}{$\%$} & Country crop origin (\%) & Ratio & Allocation \\
\hline Citrus pulp & 1.7 & BR (76), USA (24) & 9 & 0.03 \\
Soybean expeller & 12.0 & BR (48), AR (52) & 1.39 & 0.59 \\
Molasses & 4.3 & IN (100) & 4.4 & 0.30 \\
Wheat & 10.3 & NL (31), FR (7), DE (46), BE (16) & 1 & 0.85 \\
Wheat middlings & 8.9 & NL (31), FR (7), DE (46), BE (16) & 5.55 & 0.07 \\
Palm Kernel expeller & 24.9 & ID (100) & 1.90 & 0.01 \\
Maize gluten feed & 22.9 & USA (16), FR (42), DE (42) & 18.80 & 0.11 \\
Rape seed expeller & 15.1 & DE (100) & 2.71 & 0.23 \\
\hline
\end{tabular}




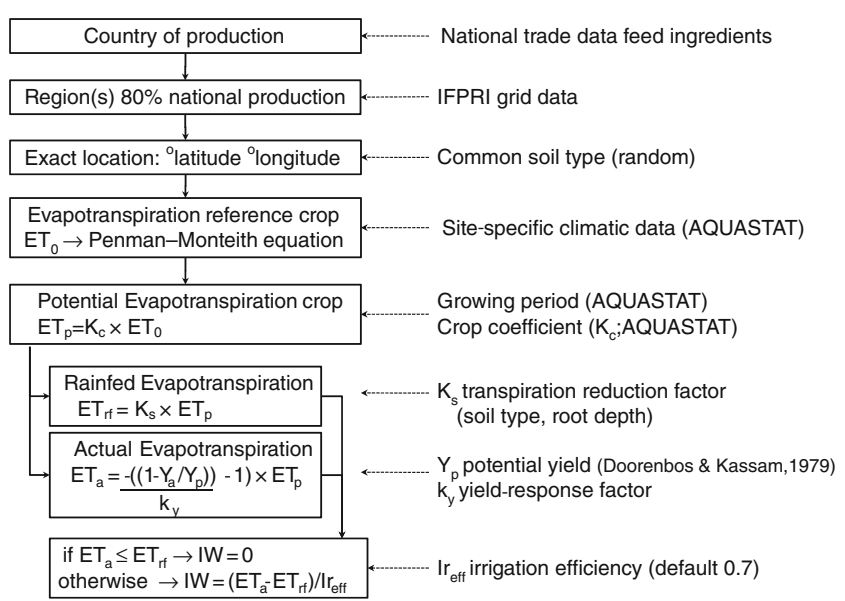

Fig. 2 Framework used to compute the amount of irrigation water (in litres per growing period) needed to cultivate feed ingredients

ingredients for dairy cows in the Netherlands originate from all over the world.

First, based on national trade data, we quantified for each feed ingredient the import percentages from various countries (see Table 3). For example, $48 \%$ of soybean expeller was assumed to originate from Brazil and the remaining $52 \%$ from Argentina. In each country, we used IFPRI grid data (You et al. 2000) to select those regions that are responsible for $80 \%$ of the national production. In each region, we first choose the most common soil type from a harmonised soil world database (FAO/IIASA/ISRIC/ISSCAS/JRC 2009). Within the entire area having this soil type, we randomly choose a location in terms of degrees in latitude and longitude.

Second, AQUASTAT (Eliasson et al. 2003) was used to compute $\mathrm{ET}_{\mathrm{O}}$ (in millimetres per day) for that specific location. $\mathrm{ET}_{\mathrm{o}}$ is the evapotranspiration of the reference crop (i.e. grass) and was computed based on the classical PenmanMonteith equation (Allen et al. 1998) and site-specific climatic characteristics, which were available in a global database (CRU CL 2.0; New et al. 2002) in AQUASTAT. This database comprises monthly grid data of observed mean climatic characteristics from 1961-1990 and covers the global surface at a 10-min spatial resolution.

Third, we used AQUASTAT to compute the potential evapotranspiration $\left(\mathrm{ET}_{\mathrm{p}}\right)$ of a crop over the growing period, i.e. the evapotranspiration assuming maximum availability of soil water (Allen et al. 1998). $\mathrm{ET}_{\mathrm{p}}$ (in millimetres per period) was computed by summing up daily values of $\mathrm{ET}_{\mathrm{p}}$ $[t]$ (in millimetres per day) over the entire cropping period as follows:

$\mathrm{ET}_{\mathrm{p}}=\int \mathrm{ET}_{\mathrm{p}}[\mathrm{t}]=\int \mathrm{K}_{\mathrm{c}}[\mathrm{t}] \times \mathrm{ET}_{\mathrm{o}}[\mathrm{t}]$

where $K_{\mathrm{c}}[t]$ is the crop coefficient at day $t$ in the growing period. The factor $K_{\mathrm{c}}$ is crop-specific, varies during the growing period and is predefined in AQUASTAT. The start and length of the growing period of a specific crop was either taken from AQUASTAT or based on literature (Netafim 2011; NDSU 2011). Fourth, we used AQUASTAT to derive evapotranspiration of the crop under rainfed conditions $\left(\mathrm{ET}_{\mathrm{rf}}\right)$. Rainfed agriculture generally implies that actual amount of soil water is lower than the maximum amount of soil water. $\mathrm{ET}_{\mathrm{rf}}$ is $\mathrm{ET}_{\mathrm{p}}$ corrected for lack of water in dryer periods depending on soil moisture and, therefore, is smaller than or equal to $\mathrm{ET}_{\mathrm{p}}$. $\mathrm{ET}_{\mathrm{rf}}$ (in millimetres per period) was computed by summing up daily values of $\mathrm{ET}_{\mathrm{rt}}[t]$ (in millimetres per day) over the entire cropping period, as the following:

$\mathrm{ET}_{\mathrm{rf}}=\int \mathrm{ET}_{\mathrm{rt}}[\mathrm{t}]=\int \mathrm{K}_{\mathrm{s}}[\mathrm{t}] \times \mathrm{ET}_{\mathrm{p}}[\mathrm{t}]$

where the transpiration reduction factor $K_{\mathrm{S}}[t]$ (value between 0 and 1) is calculated on a daily basis as a function of the maximum and actual available soil moisture in the root zone. Quantification of $K_{\mathrm{s}}[\mathrm{t}]$ requires additional information on soil type and root depth. We used default values for effective root depth as defined in AQUASTAT, except for grass and maize production in the Netherlands. Effective root depth of 0.2 for Dutch grass and 0.8 for Dutch maize were derived from field experiments of grass and maize production on loamy soils (Hoving and Van Riel 2003). $\mathrm{ET}_{\mathrm{rf}}$ is an estimate for the amount of green water as referred to in the water footprint terminology.

Fifth, from IFPRI grid data between 1995 and 2000 (You et al. 2000), we retrieved an average actual yield for each concentrate ingredient in a specific region $\left(Y_{\mathrm{a}}\right)$. Actual yields per region were averaged over the nation and compared with the national average yield in 2008 (FAO 2011). Regionspecific yield data are scaled to fit the national average yield of that crop in 2008 by multiplying with the ratio of national average yield in 2008 over the national average across 1995-2000. Actual yields for grass (10.6 tonnes DM/ha) and maize (16.5 tonnes DM/ha) on loamy soils were derived from field experiments (Hoving and Van Riel 2003). Evapotranspiration related to the actual yield $\left(\mathrm{ET}_{\mathrm{a}}\right.$ in millimetres per period) was computed based on the relationship between water supply and crop yield as described by Doorenbos and Kassam (1979):

$\mathrm{ET}_{\mathrm{a}}=-\left(\left(1-\mathrm{Y}_{\mathrm{a}} / \mathrm{Y}_{\mathrm{p}}\right) / \mathrm{k}_{\mathrm{y}}-1\right) \times \mathrm{ET}_{\mathrm{p}}$

where $Y_{\mathrm{a}}$ is the actual crop yield per hectare; $Y_{\mathrm{p}}$ is the potential crop yield per hectare; $k_{\mathrm{y}}$ is the so-called yield response factor, which is crop-specific and describes the relationship between ET deficit and yield reduction; and $\mathrm{ET}_{\mathrm{p}}$ is the potential ET requirement of the crop (in millimetres per period). The potential crop yield $\left(Y_{\mathrm{p}}\right)$ was computed based on the AgroEcological Zone method of Doorenbos and Kassam (1979). 
Finally, irrigation was assumed to be absent in case $\mathrm{ET}_{\mathrm{a}} \leq$ $\mathrm{ET}_{\mathrm{rf}}$. Otherwise, irrigation was computed as the difference between $\mathrm{ET}_{\mathrm{a}}$ and $\mathrm{ET}_{\mathrm{rf}}$ divided by $\mathrm{Ir}_{\text {eff }}$ (i.e. $\left(\mathrm{ET}_{\mathrm{a}}-\mathrm{ET}_{\mathrm{rf}}\right) / \mathrm{Ir}_{\mathrm{eff}}$ ), where $\mathrm{Ir}_{\text {eff }}$ was the irrigation efficiency implying water loss due to spraying, percolation or soil water transport. We assumed a default irrigation efficiency ( $\mathrm{Ir}_{\mathrm{eff}}$ ) of 0.7 for all crops (Allen et al. 1998), except for grass and maize production in the Netherlands. Field experiments of grass and maize production on loamy soils showed an irrigation efficiency of 0.6 for grass and 0.8 for maize land (Hoving and Van Riel 2003). The actual crop yield (DM per hectare) was used to calculate consumption of irrigation water use in litres per kilogram DM.

(2) Freshwater use for crop inputs We included consumptive water use related to production of artificial fertilisers and fossil fuels (i.e. diesel, electricity) purchased by the model dairy farm (see Table 2) and to production of energy required for processing of concentrates, based on Ecoinvent (Ecoinvent 2004). The Ecoinvent database, however, does not distinguish between consumptive and degradative water use or the environmental impact associated with water use. We, therefore, made the following additional assumptions: only $5 \%$ of the cooling water was consumptive, $95 \%$ was assumed to return to the original water body (with an increased temperature); sea water was excluded as its availability was assumed to be unlimited; and turbine water was excluded as it is considered to be in-stream water use (Batlles et al. 2010). All other water sources used (from a lake, river, well or unspecified sources) were assumed to be consumptive. These assumptions resulted in a consumptive water requirement of $4 \mathrm{~L}$ per $\mathrm{L}$ diesel, $1.3 \mathrm{~L}$ per $\mathrm{kWh}$ electricity, 14.2 L per kg N fertiliser and 99.4 L per $\mathrm{kg}_{2} \mathrm{O}_{5}$.

(3) Change in infiltration and run-off In this study, we assumed no changes in infiltration and run-off due to changes in crop management but included only changes in infiltration and run-off due to changes in land use related to production of soybean. For example, the estimated rainwater lost from a forest is about $67 \%$, whereas in arable land, this is about $73 \%$ (Mila-i-Canals et al. 2009). Changing forest into arable land, therefore, results in a $6 \%$ additional loss of rainwater. We used 440,000 L per ha (presented by Milà i Canals et al. (2009), who derived this number from Zhang et al. (1999)), as a proxy for this $6 \%$ additional loss of rainwater.

We assumed that $3.08 \%$ of the soybean was produced on land that was deforestated or transformed from Cerrado (Prudêncio da Silva et al. 2010). For each hectare of soybean, this fraction, therefore, was multiplied by $440,000 \mathrm{~L}$.

\subsubsection{Freshwater use required during dairy husbandry}

Cows on a farm require water for drinking and cleaning services. We assumed that each milking cow (including young stock) required $145 \mathrm{~L}$ of drinking and cleaning water per day (Ward and McKague 2007; Biewenga et al. 2009).

\subsubsection{Freshwater use during concentrate production}

Water use during processing of the crop (remains) into concentrates at the feed mill was assumed $4.6 \mathrm{~L}$ per tonne concentrate produced (Agrifirm (2011) Feed company, personal communication).

\subsubsection{Freshwater use required for transport}

We distinguished truck and ship transport. Consumptive water use during truck and ship transport consisted of consumptive water use related to fossil energy used for transport and consumptive water use required for cleaning transport equipment. The amount of consumptive water required per tonne per kilometre transport was based on Ecoinvent (Ecoinvent 2004). In order to determine consumptive water use related to truck or ship transport, we used the same procedure as described for energy sources or artificial fertiliser (i.e. $5 \%$ of cooling water; no sea and turbine water; all other water sources). Expressed per tonne per kilometre, consumptive water use was $0.652 \mathrm{~L}$ for truck transport, $0.16 \mathrm{~L}$ for inland ship transport and $0.029 \mathrm{~L}$ for transoceanic ship transport.

\subsection{Environmental impact of consumptive use}

The water stress index (WSI) can be used to assess the generic impact of freshwater use or in other words the mid-point indicator "water deprivation" (Pfister et al. 2009). WSI (values range from 0.01 to 1 ) is a logistic function of the total annual water withdrawal over total annual water availability, adjusted for seasonal variability in precipitation and flows, in a watershed, a region or a country (Pfister et al. 2009). In order to assess the generic impact of freshwater use on water deprivation, we multiplied total consumptive water use in each country with the average WSI of that country (Table 4), summed values across countries and related it to kilogram FPCM. The final value was normalised by dividing by the global average WSI of 0.602. Through this normalisation step, the final value shows the impact of freshwater use along the life cycle of milk relative to the impact of consumption of $1 \mathrm{~L}$ of water across the globe (Ridoutt et al. 2010b).

To assess the specific potential environmental impact related to freshwater use, we distinguished the impact on human health, the impact on ecosystem quality and resource depletion (Milà i Canals et al. 2009; Pfister et al. 2009). For each impact category, the assessment procedure is described below. 
Table 4 Value for water stress index (dimensionless, ranging from 0 to 1 ) and specific characterization factors for human health $\left(\mathrm{CF}_{\mathrm{HH}}\right.$ in $10^{-9}$ disability adjusted life years/L), ecosystem quality $\left(\mathrm{CF}_{\mathrm{EQ}}\right.$ in $10^{-3} \mathrm{~m}^{2} \times$ year/L) and resource depletion $\left(\mathrm{CF}_{\mathrm{RD}}\right.$ in kilojoules per litre) used for relevant countries (Pfister et al. 2009)

\begin{tabular}{lllll}
\hline Country & WSI & $\mathrm{CF}_{\mathrm{HH}}$ & $\mathrm{CF}_{\mathrm{EQ}}$ & $\mathrm{CF}_{\mathrm{RD}}$ \\
\hline Germany & 0.120 & 0.000 & 0.155 & 0.000 \\
Belgium & 0.715 & 0.000 & 0.157 & 0.000 \\
France & 0.181 & 0.000 & 0.146 & 0.027 \\
Netherlands & 0.306 & 0.000 & 0.193 & 0.000 \\
Brazil & 0.066 & 0.020 & 0.089 & 0.045 \\
Argentina & 0.352 & 0.036 & 0.475 & 0.954 \\
Thailand & 0.534 & 0.159 & 0.132 & 0.000 \\
USA & 0.499 & 0.002 & 0.310 & 1.870 \\
India & 0.967 & 2.240 & 0.397 & 2.820 \\
\hline
\end{tabular}

\subsubsection{Potential impact on human health}

Two impact pathways for human health can be distinguished: lack of freshwater for hygiene and human consumption and water shortage for irrigation resulting in malnutrition. The number of human deaths related to freshwater use for hygienic or consumptive purposes mainly result from poor water quality and generally not from water scarcity (Milà i Canals et al. 2009; Pfister et al. 2009). Because at this moment the link between natural water resource availability and human health is not clearly understood and extensively discussed, we omitted this aspect in the current approach (Milà i Canals et al. 2009; Pfister et al. 2009; Boulay et al. 2011b). We, however, stress the importance of incorporating water quality issues, such as human toxicity or eutrophication, in LCAs of food products as they are generally lacking (De Vries and De Boer 2010).

The damage induced by water use regarding malnutrition can be measured in disability adjusted life years (DALY). Characterization factors for malnutrition $\left(\mathrm{CF}_{\text {mal }}\right)$ are available for 175 countries worldwide (Pfister et al. 2009). Table 4 presents $\mathrm{CF}_{\text {mal }}$ for countries relevant in this study. The $\mathrm{CF}_{\text {mal }}$ is the expected specific damage per unit of water consumed and is a function of WSI, the percentage of water used in agriculture, the state of malnutrition in a country, the damage caused by malnutrition and the amount of water required to prevent malnutrition (Pfister et al. 2009). In order to assess the impact of freshwater use on malnutrition, total consumptive water use in each country was multiplied by the relevant $\mathrm{CF}_{\text {mal }}$, summed across countries and related to $1 \mathrm{~kg}$ of FPCM.

\subsubsection{Potential impact on ecosystem quality}

Consumptive freshwater use can have an impact on the quality of surrounding terrestrial ecosystems (Milà i Canals et al. 2009; Pfister et al. 2009). In water-scarce ecosystems, withdrawal of consumptive water eventually reduces availability of water for terrestrial systems and consequently affects species diversity. Table 4 shows the damage induced by consumptive water use regarding ecosystem quality for each relevant country or in other words the characterization factor for ecosystems quality $\left(\mathrm{CF}_{\mathrm{EQ}}\right)$. This characterization factor is expressed in area-time equivalents of water shortage-related vegetation damage in terms of net primary production (in square meters per year per litre).In order to assess the impact of freshwater use on ecosystem quality, total consumptive water use in each country was multiplied by the relevant $\mathrm{CF}_{\mathrm{EQ}}$ (see Table 4), values were summed across countries and related to $1 \mathrm{~kg}$ of FPCM.

\subsubsection{Impact on resource depletion}

Exhaustion of a water resource can be caused by using fossil ground water from a deposit or by overusing water from a fund or flow. Pfister et al. (2009) computed an aggregated value for the fraction of freshwater use that contributes to depletion in 175 countries (see Table 4). This characterization factor for resource depletion of each country $\left(\mathrm{CF}_{\mathrm{RD}}\right)$ equals this aggregated value times the energy required to desalinate $1 \mathrm{~L}$ of sea water (unit $\mathrm{CF}_{\mathrm{RD}}$ therefore is kilojoule per litre). In order to assess the impact of freshwater use on resource depletion, total consumptive water use in each country was multiplied by the relevant $\mathrm{CF}_{\mathrm{RD}}$ (see Table 4), values were summed across countries and related to $1 \mathrm{~kg}$ of FPCM.

\subsection{Sensitivity analyses}

All calculations were programmed in Excel, enabling us to perform a sensitivity analysis for selected parameters for our approach. The estimation of the amount of irrigation water required for on-farm grass and maize cultivation had a major impact on our final results. Prediction of on-farm irrigation water was, given a specific soil type, mainly determined by crop yield and root depth. This justifies why we explored the sensitivity of our approach regarding values used for actual crop yield and effective root depth for grass and maize cultivation on loamy soils in the Netherlands only. Sensitivity to actual crop yields was studied by exploring the effect of a $10 \%$ deviation in grass and maize production per hectare. Sensitivity for root depth was explored by studying the effect of changing effective root depth from experimental values assumed in this study to default values defined in AQUASTAT. Hence, root depth of grass was varied from $0.2 \mathrm{~m}$ (value assumed) to $0.8 \mathrm{~m}$ (default value in AQUASTAT), whereas root depth of maize was varied from $0.6 \mathrm{~m}$ (value assumed) to $1.3 \mathrm{~m}$ (default value in AQUASTAT). 


\section{Results and discussion}

\subsection{Environmental impact of consumptive water}

Table 5 shows the consumptive water use, the generic impact on water deprivation and the specific impact on human health, ecosystem quality and resource depletion per kilogram FPCM. The total amount of consumptive water used along the life cycle of milk produced on the model farm was $66 \mathrm{~L}$ per kg FPCM. About $74 \%$ of this water was used to irrigate grass and maize land on the farm itself; $15 \%$ was used to produce concentrates; $2 \%$, to produce purchased maize; and $8 \%$ was drinking and cleaning water. Consumptive water use for transport and production of purchased diesel, electricity and fertiliser was only $1 \%$.

The generic impact of production of $1 \mathrm{~kg}$ of FPCM was about $33 \mathrm{~L}\left(\mathrm{H}_{2} \mathrm{O}-\mathrm{e}\right)$, implying that production of $1 \mathrm{~kg}$ of FPCM had an equivalent impact on water deprivation as direct consumption of $33 \mathrm{~L}$ water by an average world citizen. The majority of this impact was due to production of roughage $(77 \%)$ and concentrates $(15 \%)$.

Use of water to irrigate grass or maize land in the Netherlands, however, has no impact on human health and resource depletion (i.e. characterization factors for $\mathrm{HH}$ and $\mathrm{RD}$ were zero, see Table 4). Production of $1 \mathrm{~kg}$ of FPCM on the model farm, therefore, had small impact on human health (i.e. $0.8 \times$ $10^{-9}$ DALY per kg FPCM). This impact mainly originated from production of molasses in India. The environmental impact of consumptive water use on resource depletion was $6.7 \mathrm{~kJ}$ per $\mathrm{kg}$ FPCM and mainly originated from production of maize gluten meal in the USA.

Use of water to irrigate grass or maize land in the Netherlands, however, does have an impact on ecosystem quality (i.e. characterization factor for EQ was $0.193 \times 10^{-3} \mathrm{~m}^{2} \times$ year/L, see Table 4 ). The environmental impact of consumptive water use on ecosystem quality was $12.9 \times 10^{-3} \mathrm{~m}^{2} \times$ year per kg FPCM and resulted for $75 \%$ from irrigation of

Table 5 Consumptive water use (in litres), generic impact (in litres $\mathrm{H}_{2} \mathrm{O}$-equivalants) and the impact on human health (in $10^{-9}$ disability adjusted life years), ecosystem quality (in $10^{-3} \mathrm{~m}^{2} \times$ year) and resource depletion (in kilojoules per kilogram) of fat-and-protein corrected milk

\begin{tabular}{lcclll}
\hline Stage of life cycle & CWU & GI & HH & EQ & RD \\
\hline On-farm grass cultivation & 36.8 & 18.7 & 0 & 7.1 & 0 \\
On-farm maize cultivation & 12.1 & 6.2 & 0 & 2.3 & 0 \\
Off-farm maize cultivation & 1.4 & 0.7 & 0 & 0.3 & 0 \\
Production concentrates & 10.3 & 4.9 & 0.8 & 2.2 & 6.7 \\
Dairy husbandry: drinking/cleaning & 5.4 & 2.8 & 0 & 1.0 & 0 \\
Energy sources/fertilizer & 0.3 & 0.2 & 0 & 0.1 & 0 \\
Transport & 0 & 0 & 0 & 0 & 0 \\
Total & 66.4 & 33.4 & 0.8 & 12.9 & 6.7 \\
\hline
\end{tabular}

grass and maize land on the model farm and for $17 \%$ from production of purchased concentrate ingredients.

The model farm was located in the province of Brabant, where grass and maize land is commonly irrigated. In many other regions in the Netherlands, however, irrigation of grass and maize land is far less common (Hoogeveen et al. 2003). In case we omitted on-farm irrigation of grass and maize land, production of $1 \mathrm{~kg}$ of FPCM required $16 \mathrm{~L}$ of water, the generic impact on water deprivation was $7.9 \mathrm{~L}$ $\mathrm{H}_{2} \mathrm{O}$-e, whereas the impact on EQ was $3.2 \times 10^{-3} \mathrm{~m}^{2} \times$ year. The impact on $\mathrm{HH}$ or $\mathrm{RD}$ did not change as a result of omitting on-farm irrigation. Ridoutt et al. (2010b) estimated a consumptive water use of $14.4 \mathrm{~L}$ per $\mathrm{kg}$ of milk produced. Farms analysed by Ridoutt et al. (2010b) were located in a region of Australia with plentiful water and, consequently, no irrigation water was used for on-farm roughage production. About $83 \%$ of this $14.4 \mathrm{~L}$ was assumed to be retrieved locally with an extremely low WSI of 0.013 (national WSI is 0.402 ), resulting in a generic impact on water deprivation of only $1.9 \mathrm{~L} \mathrm{H}_{2} \mathrm{O}$-e.

So far, no literature has been published regarding specific environmental impact associated with consumptive water use in milk production. Mekonnen and Hoekstra (2010a,b), however, state that "from a freshwater resource perspective, it is more efficient to obtain calories and protein through crop products than through animal products". We, therefore, compared our results with results of broccoli production in Spain and UK. Production of $1 \mathrm{~kg}$ of broccoli resulted in a consumptive blue water use of 125-175 L in Spain and of 10 60 L in UK (Milà i Canals et al. 2010). In order to determine the environmental impact associated with this consumptive water use, we assumed all water was retrieved within the country. Production of $1 \mathrm{~kg}$ of broccoli in Spain had a generic impact of 148-208 $\mathrm{L} \mathrm{H}_{2} \mathrm{O}-\mathrm{e}$, whereas the impact on $\mathrm{HH}$ was zero, the impact on EQ was $43-78 \times 10^{-3} \mathrm{~m}^{2} \times$ year and the impact of RD was 219-306 kJ. Production of $1 \mathrm{~kg}$ of broccoli in UK had a generic impact of 6.6-39.4 $\mathrm{L} \mathrm{H}_{2} \mathrm{O}-\mathrm{e}$, whereas the impact on HH was zero, the impact on EQ was 1-6.8 $10^{-3} \mathrm{~m}^{2} \times$ year and the impact of RD was $5.9-35.3 \mathrm{~kJ}$.

Production of $1 \mathrm{~kg}$ of broccoli in Spain had a higher generic impact and a higher impact on RD and EQ than production of $1 \mathrm{~kg}$ of FPCM in the model farm in the Netherlands. Production of $1 \mathrm{~kg}$ of broccoli in UK, however, had a lower to similar generic impact, a higher impact on RD, and a lower impact on EQ. As the protein content of milk and broccoli appears rather similar, these comparisons do not change when a functional unit of $1 \mathrm{~kg}$ of protein was used.

3.2 Comparison of results with water footprint concept of Hoekstra

Mekonnen and Hoekstra (2010b) estimated that production of $1 \mathrm{~kg}$ of Dutch milk (1-6\% fat), on average, required 
$544 \mathrm{~L}$ of water, of which $477 \mathrm{~L}$ was green water, $42 \mathrm{~L}$ blue water and $25 \mathrm{~L}$ grey water. Our estimate of $66 \mathrm{~L}$ blue water per kg FPCM was higher than $42 \mathrm{~L}$ from Mekonnen and Hoekstra (2010b) mainly because our model farm intensively irrigated on-farm grass and maize land, and Mekonnen and Hoekstra (2010b) modelled an average Dutch dairy farm. If we would have situated our model farm on a soil less sensitive to drought, consumptive water use was estimated at $16 \mathrm{~L}$ per kg FPCM only.

\subsection{Changes in infiltration and run-off}

The change in infiltration and run-off resulting from changes in land use with respect to soybean production appeared negligible. Per kilogram FPCM, this change was only $0.28 \mathrm{~L}$. In future computations, therefore, this aspect can be ignored, unless deforestation related to feed production will increase.

\subsection{Sensitivity analysis}

The effect of variation in root depth (grass from $0.2-0.8 \mathrm{~m}$, maize from $0.8-1.3 \mathrm{~m}$ ) on predicted values for irrigation water per hectare (in millimetres per hectare) are presented in Fig. 3 for grass and maize production in the Netherlands. As root depth increased, predicted irrigation water use decreased, for grass from 86 to $14 \mathrm{~mm} / \mathrm{ha}$ and for maize from 76 to $32 \mathrm{~mm} / \mathrm{ha}$. This has a large impact on prediction of consumptive water use and hence the environmental impact associated with this consumptive water use. In case we used AQUASTAT default values for root depth (i.e. grass $0.8 \mathrm{~m}$, maize $1.3 \mathrm{~m}$ ) instead of experimental values (i.e. grass $0.2 \mathrm{~m}$, maize $0.8 \mathrm{~m}$ ), consumptive water use per kilogram of milk decreased from 66 to $28 \mathrm{~L}$. Hence, assumptions

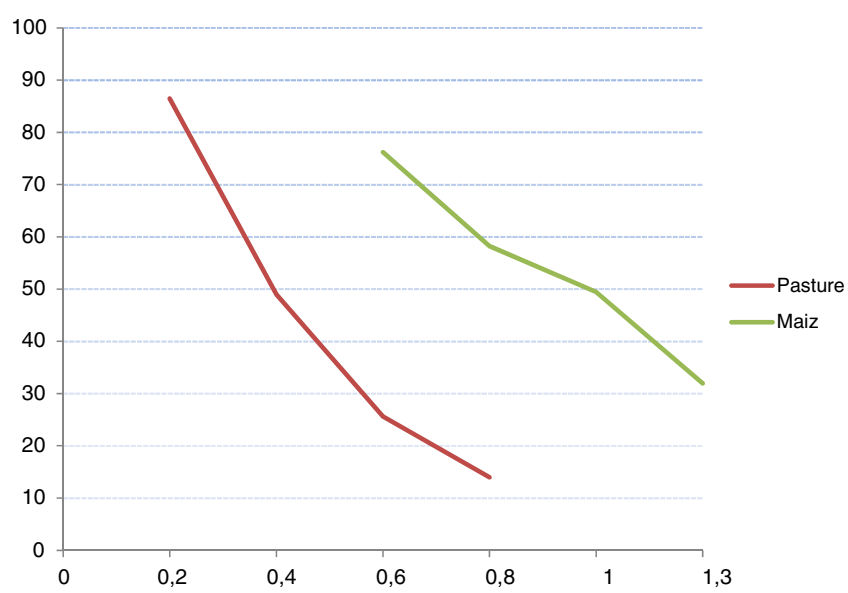

Fig. 3 Predicted values for irrigation water (y-axes in millimetres per hectare, i.e. in litres per square metre for the entire hectare) for production of grass and maize in the Netherlands for varying values of effective root depth (x-axes in metres) regarding root depth of grass and maize have a major impact on predicted values for irrigation water requirements.

Similarly, decreasing or increasing actual yield for grass and maize production per hectare by $10 \%$ decreased or increased consumptive water use by $52 \%$. A correct prediction of irrigation water requirements for feed crops, therefore, requires detailed knowledge of crop parameters, such as crop yield, soil type and root depth.

For production of concentrates, we used default values for root depth as given in AQUASTAT, which might have resulted in underestimation of consumptive water use for production of concentrates. This underestimation, however, is smaller than the default values used for root depth in grass and maize production because concentrates have a relatively high share of co-products (i.e. low economic allocation value; see Table 3).

\subsection{General discussion}

This study focussed on the mid-point and end-point environmental impacts related to consumptive freshwater use of milk production. We used a specific set of characterization factors developed by Pfister et al. (2009), as they present both mid-point and end-point factors for various countries of our interest. This choice, however, might affect final results. It was outside the scope of this research to explore variability in freshwater impacts resulting from applying different sets of characterization factors (e.g. Motoshita et al. 2011; Boulay et al. 2011b). We excluded impacts of degradative water use, which refers to withdrawal of water from a watershed and the discharge of this water with degraded quality into the same watershed (Bayart et al. 2010). Until recently, the impact of degradative water use in an LCA of, for example, milk production could be only partly addressed in the impact categories human or terrestrial eco-toxicity and eutrophication. In 2011, Boulay et al. (2011a,b), however, published a framework and characterization model to assess the impact of consumptive and degradative water use on human health, which enables including degradative water use impacts in future LCAs. Water use related to milk production mainly results from irrigation of feed crops. Possible degradation of water used for irrigation, however, not only affects human health but also results in soil salinity (Kahn and Hanjra, 2008), an impact not included in this newly developed method yet.

Results showed that consumptive water use per kilogram FPCM, on our model farm, was mainly due to irrigation water required to cultivate grass and maize on-farm. Reducing irrigation requirements for grass and maize production, therefore, could decrease consumptive water use per kilogram of FPCM. Irrigation requirement for Dutch grass and maize production might be reduced by breeding for crops with low water requirements or using techniques that 
increase irrigation efficiency. Use of irrigation water during Dutch grass and maize production, however, will affect only ecosystem quality because national characterization factors for HH and RD in the Netherlands are zero.

In this study, we used national instead of site-specific characterization factors for two reasons. First, our objective was to demonstrate that by integrating knowledge from diverse science fields, we were able to assess environmental impacts related to freshwater use along a global food chain, such as production of Dutch milk. We took a model farm in Brabant as a case study only. Second, the exact location of purchased feed ingredients was unknown. We assumed feed ingredients originated from diverse regions in a country and, therefore, used national characterization factors. If we want to compare freshwater impacts of specific dairy farms in future research, we need to invest in gathering more specific global data, especially about feed production (exact composition of concentrates, exact production location of feed crops, exact crop yields, soil type etc.). Once such highresolution global data are available, the use of site-specific instead of national characterization factors will further refine the assessment of site-specific environmental impacts of milk-producing units. As pointed out by Berger and Finkbeiner (2010), we realise the need to balance the effort (e.g. costs) to gather high-resolution global data and the need of applicability for the assessment method.

Dutch milk production showed a lower environmental impact on EQ and RD than, for example, broccoli production in Spain. This resulted from the relatively high irrigation requirements of Broccoli and the relatively high characterization factor for EQ and RD in Spain. The total footprint of Spanish broccoli (including green water use), however, was much lower $(261 \mathrm{~L})$ than that of average Dutch milk (544 L) (Mekonnen and Hoestra 2010a; 2010b). The volumetric water footprint, therefore, does not yield information about the environmental impact associated with freshwater use. Results, therefore, support earlier findings (Ridoutt et al. 2010b; Ridoutt and Pfisters 2010) that LCA needs to go beyond water volume accounting when the focus is on freshwater scarcity.

\section{Conclusions}

Integration of existing knowledge from diverse science fields enabled an assessment of freshwater impacts along the life cycle of a global food chain, such as Dutch milk production, and appeared useful to determine its environmental hotspots. Production of $1 \mathrm{~kg}$ of FPCM on a Dutch dairy farm of 32 ha, that intensively irrigated grass and maize, required $66 \mathrm{~L}$ of consumptive water. About $76 \%$ of this water was required for irrigation during roughage cultivation (mainly on-farm), $15 \%$ for production of concentrates and $8 \%$ for drinking and cleaning. Consumptive water use related to production of purchased diesel, gas, electricity and fertiliser was negligible (i.e. total $1 \%$ ). Production of $1 \mathrm{~kg}$ of FPCM resulted in an impact on human health of $0.8 \times 10^{-9}$ DALY, on ecosystem quality of 13 $10^{-3} \mathrm{~m}^{2} \times$ year and on resource depletion of $6.7 \mathrm{~kJ}$. The impact on resource depletion was lower than the environmental impact of production of, for example, $1 \mathrm{~kg}$ of broccoli in Spain or UK. Results from this case study, therefore, support earlier findings that LCA needs to go beyond simple water volume accounting when the focus is on freshwater scarcity. The approach used, however, required high resolution inventory global data (i.e. especially regarding crop yield, soil type and root depth) and demonstrated a tradeoff between scientific quality of results and applicability of the assessment method.

Open Access This article is distributed under the terms of the Creative Commons Attribution License which permits any use, distribution, and reproduction in any medium, provided the original author(s) and the source are credited.

\section{References}

Allen RG, Pereira LS, Raes D, Smith M (1998) Crop evapotranspiration: guidelines for computing crop water requirements, FAO Drainage and Irrigation Paper 56. FAO, Rome

Batlles FJ, Rosiek S, Munoz I, Fernandez-Alba AR (2010) Environmental assessment of the CIESOL solar building after two years operation. Environ Sci Technol 44:3587-3593

Bayart JB, Bulle C, Deschenes L, Margni M, Pfister S, Vince F, Koehler A (2010) A framework for assessing off-stream freshwater use in LCA. Int J Life Cycle Assess 15:439-453

Berger M, Finkbeiner M (2010) Water footprinting: how to address water use in a life cycle assessment? Sustainability 2:919-944

Biewenga G, Van Middelkoop J, Ouweltjes W, Remmelink G, Wemmerhove H (2009) Handboek voor de melkveehouderij. Animal Sciences Group, Wageningen UR Livestock Research, Lelystad

Boulay A-M, Bouchard C, Bulle C, Deschênes L, Margni M (2011a) Categorizing water for LCA inventory. Int J Life Cycle Assess 16:639-651

Boulay A-M, Bulle C, Bayart J-B, Deschênes L, Margni M (2011b) Regional characterization of freshwater use in LCA: modelling direct impacts on human health. Environ Sci Technol 45:89488957

Chapagain AK, Orr S (2009) An improved water footprint methodology linking global consumption to water resources: a case study of Spanish tomatoes. J Environ Manage 90:1219-1228

Chapagain AK, Hoekstra AY, Savaneije HHG, Gautam R (2006) The water footprint of cotton production: an assessment of the impact of worldwide consumption of cotton products on the water resources in the cotton producing countries. Ecol Econ 60:186-203

CVB (2008) Book of tables 2008: feed norms for livestock and feed values of feed (Tabellenboek Veevoeding 2008: Voedernormen Landbouwhuis-dieren en Voederwaarden Veevoeders). Central Bureau Animal Feed, Lelystad 
De Vries M, De Boer IJM (2010) Comparing environmental impacts for livestock products: a review of life cycle assessments. Livest Sci 128:1-11

Doorenbos J, Kassam AH (1979) Yield response to water function. FAO Irrigation and Drainage Paper No. 33. Rome, Italy

Ecoinvent (2004) Ecoinvent data v1.1 final reports Ecoinvent, Swiss Centre for Life Cycle Inventories, Dubendorf

Eliasson A, Faurès J-M, Frenken K, Hoogeveen J (2003) AQUASTAT - Getting to grips with water information for agriculture. Land and Water Development Division FAO, Rome, Italy (http:// www.fao.org/ag/aquastat. Accessed January 2011)

FAO (2011) FAOSTAT on-line database, Food and Agriculture Organization, Rome, http://faostat.fao.org. Accessed January 2011

FAO/IIASA/ISRIC/ISSCAS/JRC (2009) Harmonized world soil database (version 1.1). FAO, Rome, Italy and IIASA, Laxenburg, Austria

Finnveden G (1996) Resources and related impact categories, Part III. In: Udo De Haes H (ed) Towards a methodology for life cycle impact assessment. Society for Environmental Toxicology and Chemistry-Europe, Brussels

Guinée JB, Gorrée M, Heijungs R, Huppes G, Kleijn R, De Koning A, Van Oers L, Wegener Sleeswijk A, Suh S, Udo De Haes HA, De Bruijn H, Van Duin R, Huijbregts MAJ, Lindeijer E, Roorda AAH, Van der Ven BL, Weidema BPE (2002) Handbook on life cycle assessment. Operational guide to the ISO standards. Institute for Environmental Sciences, Leiden

Hoekstra AY, Hung PQ (2002) Virtual water trade: a quantification of virtual water flows between nations in relation to international crop trade. Value of water research report series No. 11: UNESCO-IHE Institute for water education, Delft, The Netherlands (http:// www.waterfootprint.org/Reports/Report11.pdf)

Hoekstra AY, Chapagain AK, Aldaya MM, Mekonnen MM (2009) Water footprint manual: state of the Art 2009. Water Footprint Network, Enschede, The Netherlands, http://www.waterfootprint.org/ downloads/ WaterFootprintManual2009.pdf

Hoogeveen MW, Van Bommel KHM, Cotteleer G (2003) Beregening in land- en tuinbouw; Rapport voor de Droogtestudie Nederland. Agricultural Economics Research Institute, The Hague

Hoving IE, Van Riel JW (2003) Het effect van diverse beregeningsstrategieën op de opbrengst van gras. Nederlandse Vereniging voor Weide en Voederbouw. Research report series nr. 39, 20022003, The Netherlands

IDF (2010) A common carbon footprint approach for dairy. The IDF guide to standard life cycle assessment methodology for the dairy sector. Bulletin of the International Dairy Federation 445

Khan S, Hanjra MA (2008) Sustainable land and water management policies and practices: a pathway to environmental sustainability in large irrigation systems. Land Degrad Dev 19:469-487

Koehler A (2008) Water use in LCA: managing the planet's freshwater resources. Int J Life Cycle Assess 13:451-455

Lindeijer E, Müller-Wenk R, Steen B (2002) Impact assessment of resources and land use. In: Udo De Haes HA, Finnveden G, Goedkoop M, Hausschild M, Hertwich EG, Hofstetter P, Jolliet O, Klöpffer W, Krewitt W, Lindeijer EW, Müller-Wenk R, Olsen SI, Pennington DW, Potting J, Steen B (eds) Life cycle impact assessment: striving towards best practice. SETAC, Pensacola, pp 11-64

Mekonnen MM, Hoekstra AY (2010a) The green, blue and grey water footprint of crops and derived crop products. Value of water research report series No.47. UNESCO-IHE. Institute for Water Education, Delft, The Netherlands
Mekonnen MM, Hoekstra AY (2010b) The green, blue and grey water footprint of farm animals and animal products. Value of water research report series No.48. UNESCO-IHE. Institute for Water Education, Delft, The Netherlands

Milà i Canals L, Chenoweth J, Chapagain A, Orr S, Antón A, Clift R (2009) Assessing freshwater use impacts in LCA: Part I-inventory modelling and characterisation factors for the main impact pathways. Int J Life Cycle Assess 14:28-42

Milà i Canals L, Chenoweth J, Chapagain A, Orr S, Antón A, Clift R (2010) Assessing freshwater use impacts in LCA: Part 2: case study of broccoli production in the UK and Spain. Int J Life Cycle Assess 15:598-607

Motoshita M, Itsubo N, Inaba A (2011) Development of impact factors on damage to health by infectious diseases caused by domestic water scarcity. J Life Cycle Assess 16:65-73

NDSU (2011) North Dakota State University (NDSU) agriculture, http:// www.ag.ndsu.edu/pubs/plantsci/rowcrops/a1173/a1173w.htm, Accessed January 2011

Netafim (2011) http://www.sugarcanecrops.com/agronomic_practices/ planting time. Accessed January 2011

Nevedi (2008) Lineaire programmeringen rundvee-, varkens- en pluimveevoeders. Monthly reports on feed composition computed by Schothorst Feed Research BV, Lelystad, The Netherlands

New M, Lister D, Hulme M, Makin I (2002) A high-resolution data set of surface climate over global land areas. Clim Res 21:1-25

Oki T, Kanae S (2006) Global hydrological cycles and world water resources. Science 313:1068-1072

Pfister S, Koehler A, Hellweg S (2009) Assessing the Environmental Impacts of Freshwater Consumption in LCA. Environ Sci Technol 43:4098-4104

Prudêncio da Silva V, Van der Werf HMG, Spies A, Roberto Soares S (2010) Variability in environmental impacts of Brazilian soybean according to crop production and transport scenarios. J Environ Manage 91:1831-1839

Ridoutt BG, Pfister S (2010) A revised approach to water footprinting to make transparent the impacts of consumption and production on global water scarcity. Global Environ Change 20:113-120

Ridoutt BG, Eady SJ, Sellahewa J, Simons L, Bektash R (2009) Water footprinting at the product brand level: case study and future challenges. J Cleaner Prod 17:1228-1235

Ridoutt BG, Williams SRO, Baud S, Fraval S, Marks N (2010) The water footprint of dairy products: case study involving skim milk powder. J Dairy Sci 93:5114-5117

Smakthin,VU, Revenga C, Döll P (2004) Taking into account environmental water requirements in global-scale water resources assessments. Research report of the CGIAR comprehensive assessment of water management in agriculture. No. 2, International Water Management Institute, Colombo, Sri Lanka

Steinfeld H, Gerber P, Wassenaar T, Castel V, Rosales M, De Haan C (2006) Livestock's long shadow: environmental issues and options. FAO, Rome

Ward D, McKague K (2007) Water requirements of livestock. Factsheet Ministry of Agriculture. Food and Rural Affairs, Ontario

You L, Crespo S, Guo Z, Koo J, Ojo W, Sebastian K, Tenorio MT, Wood S, Wood-Sichra U (2000) Spatial production allocation model (SPAM) 2000 Version 3 Release 2. http://MapSPAM.info (Accessed January 2011)

Zhang L, Dawes WR, Walker GR (1999) Predicting the effect of vegetation changes on catchment average water balance. Technical Report 99/12. Cooperative Research Centre for Catchment Hydrology, Canberra, Australia 